\title{
Inhalt, Vol. 10, No. 3, 1987
}

\section{Contents}

Impressum 110

Editorial 112

Diehl, V. und Pfreundschuh, M., Köln

Klinische Relevanz der Immuntypisierung onkologischer und

hämatologischer Erkrankungen $\quad 114$

Emmrich, F.,Erlangen

Perspektiven der Anwendung monoklonaler Antikörper in der

Therapie neoplastischer Erkrankungen $\quad 121$

Bartram, C. R., Ulm

Molekulargenetische Untersuchungen zur Pathogenese und

Klassifizierung der chronisch myeloischen Leukämie

Pandolfi, F.; Cafaro, A. und Scarselli, E., Rom lltalien

Relevanz der Phänotypisierung von monoklonalen Antikörpern und gentechnischer Studien bei der Klassifizierung von T-ZellLeukämie/Lymphomen 134

Kleihauer, E., Ulm

Diagnostik und Therapieansätze mit gentechnologischen Methoden bei Thalassämien 138

Fauser, A. A. und Howson-Jan, K., Montreal/Kanada,

Kanz, B. und L·öhr, G. W., Freiburg

Immunregulation der Hämatopoese 144

Níssen, C, BasellSchweiz

Serumfaktoren und deren Einfluß auf die Hämatopoese

Hinweise für Autoren 156

Midler, C. A.; Busch, F. W. und Waller, H. D., Tubingen

Bedeutung des HLA-Systems in der Regulation der Hämato

poese 157

Storb, R. und Witherspoon, R., Seattle, WA./USA

Welche Faktoren entscheiden über Erfolg oder Mißerfolg der

Knochenmarktransplantation?

166

Bacigalupo, A.; Piaggio, G.; van Lint, M. T.; Figari, O.;

Marmont, A. und Congiu, M., Genualltalien

Aplastische Anämie: Pathogenese und Behandlung 172

Niethammer, D., Tubingen

Störungen der Hämatopoese bei Immundefekten

Informationen für die Klinik 180

Imprint 110 
Editorial 112

Diehl, V. and Pfreundschuh, M., Köln

Clinical Relevance of Immunotyping of Hematological and

Oncological Diseases 114

Emmrich, F., Erlangen

Possible Applications of Monoclonal Antibodies for Therapy of

Neoplastic Diseases 121

Bartram, C. R., Ulm

Moleculargenetic Analyses of Chronic Myelocytic Leukemia:

Implications for Pathogenesis and Classification 127

Pandolfi, F.; Cafaro, A. and Scarselli, E., Rome/Italy Relevance of Monoclonal Antibody

Phenotyping and of Genetic Studies in the Classification of T-Cell Leukemia/Lymphoma . . 134

Kleihauer, E., Ulm

Gene Technology: Application for Diagnosis, Prevention, and

Therapy of Thalassemias 138

Fauser, A. A. and Howson-Jan, K., Montreal/Canada,

Kanz, B. and Löhr, G. W., Freiburg

Immune Regulation of Hematopoiesis

144

Nissen, C, Basel/Switzerland

Human Serum Factors and Their Effect on Hematopoiesis .... 153

Instructions for Authors 156

Müller, C. A.; Busch, F. W. and Waller, H. D., Tubingen Influence of the HLA-System on

Regulation of Hematopoiesis . 157

Storb, R. and Witherspoon, R., Seattle, WA./U.S.A.

Marrow Transplantation: What Determines Success or Failure of

Hematologic Reconstitution? 166

Bacigalupo, A.; Piaggio, G.; van Lint, M. T; Figari, O.;

Marmont, A. and Congiu, M., Genoa/Italy

Aplastic Anemia: Pathogenesis and Treatment 172

Niethammer, D., Tubingen

Disturbances of Hematopoiesis in Immunodeficiencies 174

Clinical Information 180

Teil II wird in der ONKOLOGIE 4/August 1987 publiziert. Die Beiträge von Teil I + II wurden zusammengestellt von: H.D. Waller und B.Steinke, Med. Klinik der Universität Tubingen.

Beilagenhinweis: Dieser Ausgabe liegt ein «Congress Report» der Firma von Heyden bei. Ein

Teil dieser Ausgabe enthält die Beilage «lmmunomodulation».

Bibliographischer Hinweis: Inhaltsverzeichnisse dieser Zeitschrift erscheinen regelmäßig in current contents ${ }^{\circledR}$ sowie in anderen bibhographischen Diensten. 